\title{
PENGEMBANGAN VIDEO PEMBELAJARAN PADA TEMA 8 SUBTEMA 1 MATERI MANUSIA DAN LINGKUNGAN KELAS V
}

\author{
Muchammad Farid, Susilaningsih, Yerry Soepriyanto \\ Teknologi Pendidikan, Fakultas Ilmu Pendidikan, Universitas Negeri Malang. \\ Jl. Semarang No.5, Malang, 65145, Indonesia. \\ Muchammadfarid12@gmail.com
}

\section{Article History}

Received: 20 September 2020, Accepted: 19 Maret 2021, Published: 20 Februari 2022

\begin{abstract}
Abstrak
Pengembangan ini dilaksanakan dengan tujuan menghasilkan produk video pembelajaran materi manusia dan lingkungan yang telah melalui proses validasi pada tema 8 subtema 1 pembelajaran 1 materi manusia dan lingkungan. Penelitian ini menggunakan model pengembangan Sadiman, langkah-langkah pengembangannya diantaranya analisis kebutuhan, perumusan tujuan, pengembangan materi, pengembangan alat evaluasi, menyusun naskah, produksi, tes atau uji coba, revisi, produk siap diaplikasikan. Subjek pengguna pada pengembangan ini adalah anak didik kelas VB MI Ar-Raudhah Lawang. Jenis data yang diaplikasikan yaitu kualitatif (instrumen ahli media, ahli materi, dan anak didik) dan data kuantitatif (tes hasil belajar). Berdasarkan hasil penelitian dapat dikaji bahwa video pembelajaran ini valid dan layak diaplikasikan sebagai sumber belajar yang efektif serta mampu menunjang hasil belajar anak didik dalam tema 8 subtema 1 pembelajaran 1 materi manusia dan lingkungan. Dengan demikian, video pembelajaran yang di aplikasikan pada tema 8 subtema 1 pembelajaran 1 materi manusia dan lingkungan dapat menjadi solusi bagi para pendidik untuk mempermudah proses pembelajaran.
\end{abstract}

Kata kunci: Video Pembelajaran; Tematik; Manusia dan Lingkungan; SD

\begin{abstract}
This development is carried out with the aim of producing learning video products for human and environmental materials that have gone through the validation process on theme 8 sub-themes 1 learning 1 human and environmental material. This research uses Sadiman's development model, the development steps include needs analysis, goal formulation, material development, evaluation tool development, manuscript drafting, production, test or trial, revision, product ready for application. The user subjects in this development were students in class VB MI Ar-Raudhah Lawang. The type of data applied is qualitative (media expert instruments, material experts, and students) and quantitative data (learning outcome tests). Based on the research results, it can be seen that this learning video is valid and feasible to be applied as an effective learning resource and is able to support student learning outcomes in the theme of 8 sub-themes 1 learning 1 human and environmental material. Thus, the learning video applied to the theme 8 sub-themes 1 learning 1 human and environmental material can be a solution for educators to simplify the learning process.
\end{abstract}

Keyword: Instructional video; Thematic; Human and Environment; Elementary School 


\section{PENDAHULUAN}

Pada era ini muncul bermacam-macam problematika dalam ranah pendidikan menuntut para pendidik agar menemukan jalan keluar yang tepat guna mengatasinya. Seperti halnya meningkatkan kualitas tenaga pendidik, seperti dengan mengadakan pelatihan yang berkualitas. Hal tersebut dilihat dengan banyaknya pendidik masih menerapkan konsep mengajar konvesional yang cukup tertinggal untuk diimplikasikan di era ini, dimana pendidik sebagai titik vital kualitas anak didiknya. Pemanfaatan media guna menunjang belajar bagi anak didik adalah salah satu solusi yang mampu mendukung para pendidik mengatasi permasalahan pembelajaran di era ini. Media adalah salah satu sarana yang mempunyai pengaruh besar dalam dunia pendidikan. Media menjadi hal vital seperti halnya sebagai sarana untuk menghafal dan mengembangkan pemikiran mengenai materi yang terdapat didalamnya. Dilihat dari masalah sebelumnya yaitu pengembangan pemikiran anak didik harus diselaraskan dengan menghafal. Dengan beberapa solusi tersebut diharapkan dapat mengatasi permasalahan pendidikan yang terjadi saat ini. Hal ini dimungkinkan, apabila penerapan kurikulum saat ini dapat menjadikan anak didik yang lebih kreatif, berkarakter, produktif dan inovatif.

Media pada pengembangan ini menggunakan video guna media pembelajaran. Media video adalah media yang menyajikan audio dan visual yang berisi informasi pembelajaran baik yang bersifat konsep, prinsip, prosedur, teori aplikasi pengetahuan guna untuk mendukung pemahaman peseta didik dalam memahami suatu informasi pada saat aktivitas belajar mengajar (Riyana, 2007; Hernawan, Zaman, dan Riyana, 2007; Susilana, Si, dan Riyana, 2008; Praherdhiono \& Adi, 2008). Media video merupakan cara menyampaikan atau menghasilkan materi dengan memanfaatkan mesin-mesin mekanis dan elektronik guna menyajikan pesan-pesan audio visual (Arsyad, 2006). Materi yang disampaikan melalui media dengar dan media gambar (audiovisual) akan dapat mudah dipahami dengan baik karena terlihat secara visual dan terdengar secara audio. Jadi video merupakan media berupa audiovisual, berupa gambar dan audio yang bergerak secara teratur guna mendukung anak didik memahahami materi pembelajaran. Video merupakan salah satu media pembelajaran yang menarik untuk diimplementasikan dalam aktivitas belajar mengajar. Media pembelajaran yang menarik membuat proses pembelajaran menjadi tidak jenuh bagi anak didik dan dapat meningkatkan daya tarik anak didik terhadap materi pembelajaran. Kemenarikan dalam media video tidak dimiliki oleh jenis media lainnya (Pramudito, 2013; Melinda, Degeng, dan Kuswandi, 2018; Agustiningsih, 2015). Hal lain yang dapat diperhatikan dalam memanfaatkan media video pembelajaran yaitu kelengkapan desain pesan yang disajikan untuk mewadahi semua karakteristik belajar anak didik. Hal itu didasarkan pada teori bahwa karakteristik dan gaya belajar setiap anak didik berbeda (R. Mayer dan Mayer, 2005; R. E. Mayer dan Moreno, 1998; Surahman dan Surjono, 2017).

Pada observasi yang telah dilaksanakan di MI Ar-Raudhah Lawang pada tema 8 subtema 1 pembelajaran 1 materi manusia dan lingkungan untuk kelas $\mathrm{V}$ dalam pengembangan materi dan penekanan visualisasi manusia dan lingkungan didapati anak didik kurang menguasai materi. anak didik memiliki minat yang tinggi dalam mempelajari materi manusia dan lingkungan, akan tetapi terdapat faktor penghambat seperti kurang adanya media pembelajaran yang tepat dan layak dalam mengembangkan teori hafalan untuk tema 8 subtema 1 pembelajaran 1 materi manusia dan lingkungan untuk kelas V di MI Ar-Raudhah Lawang. Dilihat dari permasalahan tersebut, media mempunyai peran penting dalam membantu mengoptimalkan aktivitas pembelajaran, membantu para anak didik untuk mengembangkan teori mengenai materi terkait dan mampu menunjang proses pembelajaran anak didik.

Berdasarkan observasi di lapangan dan kajian dari beberapa penelitian sebelumnya, maka pengembangan ini bertujuan untuk menemukan solusi pembelajaran yang inovatif dengan 
pemanfaatan teknologi yang berkembang. Manfaat yang diharapkan pada penelitian ini adalah mampu membuat anak didik mudah dalam memahami materi manusia dan lingkungan pada tema 8 subtema 1 pembelajaran 1 materi manusia dan lingkungan untuk kelas $\mathrm{V}$, membantu para pendidik dalam menyiapkan materi dengan mudah, meningkatkan minat anak didik dalam pembelajaran, serta memudahkan mengembangkan materi dan pengaplikasiannya aktivitas pembelajaran, mengembangankan imajinasi anak didik dengan kemenarikan audio visual yang terkandung dalam video, dan kegunaan lainnya.

\section{METODE}

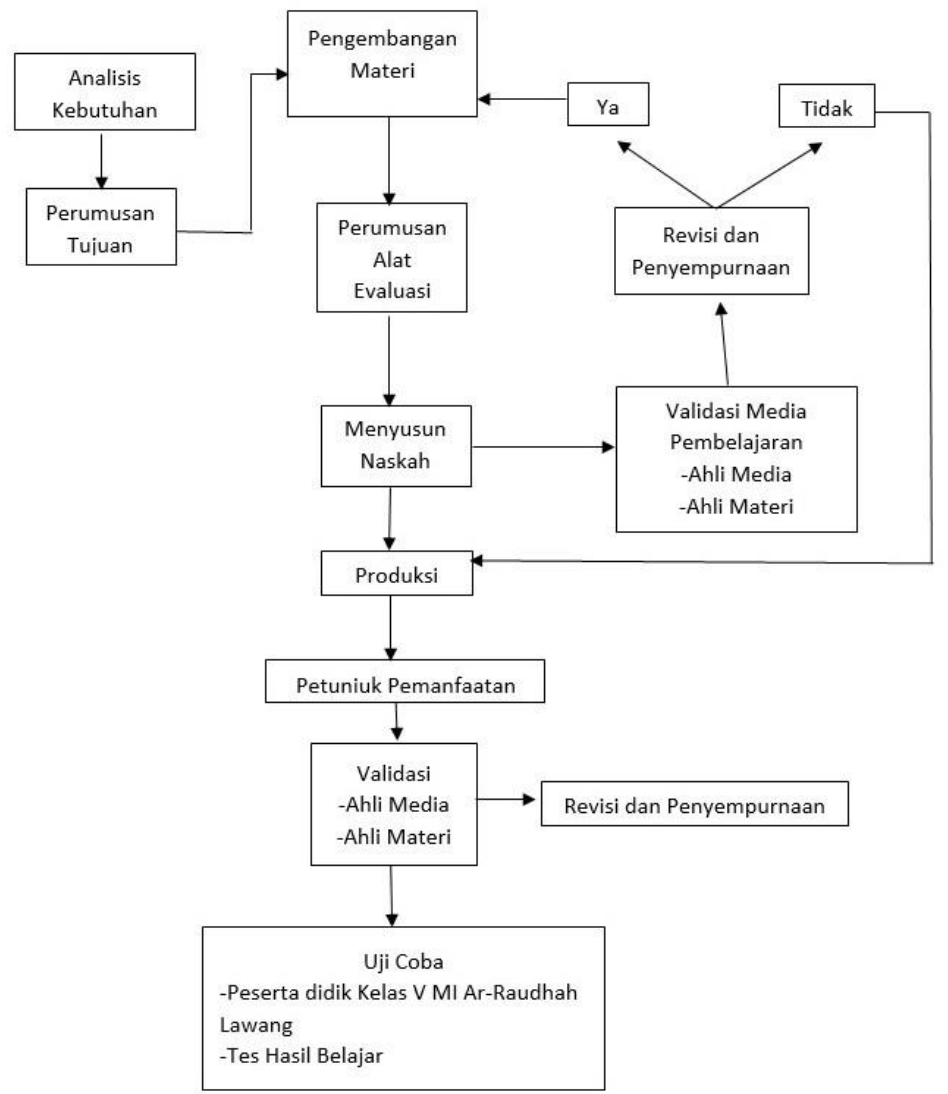

Gambar 1. Prosedur pengembangan media pembelajaran Sadiman dkk (2011)

Langkah yang dilakukan dalam pengembangan video pembelajaran yaitu menentukan terlebih dahulu prosedur yang akan dilaksanakan. Pengembangan video pembelajaran merujuk pada langkah-langkah yang tertera pada bentuk bagan oleh Sadiman (2011).

Dalam pengembangan media video pembelajaran tema 8 subtema 1 pembelajaran 1 materi manusia dan lingkungan untuk kelas V di MI Ar-Raudhah Lawang disesuaikan dengan kebutuhan uji coba diantaranya, ahli materi yaitu guru anak didik kelas V di MI Ar-Raudhah Lawang dan ahli media yaitu merupakan instruktur jurusan Teknologi Pendidikan Universitas Negeri Malang, dan responden yang merupakan anak didik kelas V di MI Ar-Raudhah Lawang yang totalnya 22 anak didik. Data yang diimplikasikan pada pembuatan media video pembelajaran ini adalah menerapkan sarana penelitian atau instrumen berbentuk data pendapat keabsahan validasi ahli materi, data pendapat keabsahan validasi ahli media, data pendapat respon anak didik, dan tes hasil belajar anak didik (pre-test dan post-test). Teknik analisis data yang diimplikasikan dalam pengembangan media video pembelajaran ini yaitu skor data pendapat dan tes hasil belajar. Poin data pendapat berbentuk penilaian yang didistribusikan oleh ahli materi, ahli media, dan anak didik. Sementara itu, skor tes hasil belajar anak didik dihasilkan dari tugas yang telah dilakukan kepada anak didik. 
Video pembelajaran tema 8 subtema 1 pembelajaran 1 materi manusia dan lingkungan untuk kelas $\mathrm{V}$ yang dikembangkan dapat dinyatakan layak dan sesuai dengan nilai validitas media apabila mencapai skor minimal 80\% kriteria analisis produk dari Arikunto dan Jabar (2014). Pengelolaan data tes pencapaian belajar anak didik dalam penelitian ini ditentukan pada perhitungan hasil tes bahan uji coba. Uji coba dilakukan terhadap anak didik kelas V di MI ArRaudhah Lawang. Proses perhitungkan tes pencapaian belajar anak didik yaitu dengan membandingkan nilai anak didik dengan kriteria ketuntasan minimum (KKM) sebesar 70.

\section{HASIL}

Hasil tes belajar penelitian ini dihasilkan dengan cara menghitung hasil tes subjek uji coba kepada 22 anak didik MI Ar-Raudhah Lawang pada tingkatan kelas 5. Cara menghitung data tes hasil belajar yaitu didasarkan pada KKM atau Kriteria Ketuntasan Minimal pada tema 8 subtema 1 pembelajaran 1 materi manusia dan lingkungan untuk kelas V MI Ar-Raudhah Lawang. Bedasarkan hasil penelitian produk media pembelajaran video tema 8 subtema 1 pembelajaran 1 materi manusia dan lingkungan untuk kelas V MI Ar-Raudhah Lawang.

\section{Tabel 1. Penyajian Data Hasil Validasi Ahli Materi}

\begin{tabular}{clc}
\hline No & \multicolumn{1}{c}{ Indikator } & X \\
\hline 1 & Kesesuaian isi media video pembelajaran dengan kurikulum 2013 & 4 \\
2 & Kejelasan isi materi manusia dan lingkungan dengan menggunakan media video & 4 \\
3 & $\begin{array}{l}\text { Kesesuaian tulisan grafis dalam menjelaskan materi dengan tayangan video yang } \\
\text { ditampilkan }\end{array}$ & 4 \\
4 & $\begin{array}{l}\text { Ketepatan penggunaan media video pembelajaran untuk pokok bahasan manusia } \\
\text { dan lingkungan }\end{array}$ & 4 \\
5 & Kejelasan keterangan dalam materi video pembelajaran manusia dan lingkungan & 3 \\
6 & Urutan materi yang disampaikan melalui media video pembelajaran & 4 \\
7 & Kemudahan materi untuk dipahami oleh anak didik & 3 \\
8 & Kemenarikan materi yang disampaikan dengan menggunakan video pembelajaran & 4 \\
9 & Kesesuaian formatan video dengan materi yang disampaikan & 4 \\
10 & Kesesuaian alat evaluasi media video pembelajaran dalam pembelajaran tema 8 & 4 \\
& subtema 1 pembelajaran 1 materi manusia dan lingkungan & 3.8 \\
\hline \multicolumn{2}{l}{ Rata-rata }
\end{tabular}

Pada angket penelitian ahli materi sebanyak $80 \%$ indikator mendapat tanggapan sangat setuju dan $20 \%$ mendapat tanggapan setuju dari ahli materi seperti yang disajikan pada tabel 1. Sehingga pada angket penelitian ahli materi, rata-rata jawaban dari ahli materi yaitu 3.8 dari skor maksimal 4 dengan persentase. Dari skala data keabsahan ahli materi tersebut, kemudian dilaksanakan rekapitulasi untuk keseluruhan perspektif.

\section{Tabel 2. Penyajian Data Hasil Validasi Ahli Media}

\begin{tabular}{clc}
\hline No & \multicolumn{1}{c}{ Indikator } & X \\
\hline 1 & kesesuaian materi untuk ditampilkan dalam bentuk video & 4 \\
2 & kesesuaian media video pembelajaran dengan pencapaian tujuan pembelajaran & 3 \\
3 & kesesuaian antara suara penjelasan narator dengan gambar yang ditayangkan & 4 \\
4 & kemenarikan video pembelajaran secara keseluruhan & 3 \\
5 & ketepatan komposisi gambar dalam tayangan video & 4 \\
6 & kejelasan gambar yang ditanyakan secara keseluruhan & 4 \\
7 & kelengkapan isi petunjuk pemanfaatan & 2 \\
8 & kejelasan tulisan grafis yang muncul dalam tayangan media video pembelajaran & 4 \\
9 & kesesuaian desain media video pembelajaran dengan materi pembelajaran manusia & 4 \\
& dan lingkungan & 3 \\
\hline Rata-rata & kesesuaian musik pembuka, pengiring dan penutup & 3.5 \\
\hline
\end{tabular}

Pada angket penelitian ahli media sebanyak $60 \%$ indikator mendapat tanggapan sangat setuju, $30 \%$ mendapat tanggapan setuju dan 10\% indikator mendapat tanggapan cukup dari ahli materi.. 
Sehingga rata-rata jawaban ahli media adalah 3.5 dari skor maksimal 4. Dari skala data keabsahan ahli media tersebut, kemudian dilaksanakan rekapitulasi untuk keseluruhan perspektif. Berlandaskan pengorganisasian data ahli media yang telah dikumpulkan, dihasilkan tingkat persentase keseluruhan aspek sebanyak $87.5 \%$. Berlandaskan tafsiran data, tergolong dalam kualifikasi A dengan persentase $85 \%$ - 100\% maka media yang diciptakan tersebut tergolong dalam kualitas valid dan layak diaplikasikan untuk proses belajar mengajar.

Tabel 3. Penyajian Data Hasil Validasi Satu Lawan Satu

\begin{tabular}{clc}
\hline No & \multicolumn{1}{c}{ Indikator } & $\mathbf{X}$ \\
\hline 1 & kejelasan judul program dalam tayangan video pembelajaran & 8 \\
2 & kejelasan materi dalam tayangan video pembelajaran & 7 \\
3 & kualitas media video pembelajaran & 8 \\
4 & kejelasan teks dalam video pembelajaran & 7 \\
5 & kejelasan suara narator pada video pembelajaran & 8 \\
6 & kejelasan audio pada video pembelajaran & 8 \\
7 & kesesuaian tempo musik dengan gambar video & 7 \\
8 & kemenarikan video pembelajaran secara keseluruhan & 7 \\
9 & mempermudah anak didik dalam memahami materi pembelajaran & 8 \\
10 & anak didik mendapat pengetahuan baru dari video pembelajaran & 8 \\
\hline \multicolumn{2}{l}{ Rata-rata } & 7.6 \\
\hline
\end{tabular}

Dalam uji coba pada satu lawan satu dilakukan penelitian berbentuk angket sebanyak 10 butir pertanyaan yang dibagikan kepada 2 responden. Sebanyak $60 \%$ indikator mendapat tanggapan sangat setuju dan $40 \%$ indikator mendapat tanggapan setuju dari audiens uji coba kelompok kecil. Sehingga dihasilkan nilai 7.6 dari 8. Kemudian dilaksanakan rekapitulasi untuk keseluruhan perspektif. Berlandaskan pengorganisasian data uji coba kelompok kecil yang telah dikumpulkan, dihasilkan tingkat persentase keseluruhan aspek sebanyak 98,75\%. Berlandaskan tafsiran data, tergolong dalam kualifikasi A dengan persentase 85\% - 100\% maka media yang diciptakan tersebut tergolong dalam kualitas valid dan layak diaplikasikan untuk proses belajar mengajar.

Tabel 4. Penyajian Data Hasil Validasi Kelompok Kecil

\begin{tabular}{clc}
\hline No & \multicolumn{1}{c}{ Indikator } & $\mathbf{X}$ \\
\hline 1 & Kejelasan judul program dalam tayangan video pembelajaran & 40 \\
2 & Kejelasan materi dalam tayangan video pembelajaran & 39 \\
3 & Kualitas media video pembelajaran & 40 \\
4 & Kejelasan teks dalam video pembelajaran & 38 \\
5 & Kejelasan suara narator pada video pembelajaran & 40 \\
6 & Kejelasan audio pada video pembelajaran & 39 \\
7 & Kesesuaian tempo musik dengan gambar video & 40 \\
8 & Kemenarikan video pembelajaran secara keseluruhan & 39 \\
9 & Mempermudah anak didik dalam memahami materi pembelajaran & 40 \\
10 & Anak didik mendapat pengetahuan baru dari video pembelajaran & 40 \\
\hline Rata-rata & 39.5 \\
\hline
\end{tabular}

Dalam uji coba pada kelompok kecil dilakukan penelitian berbentuk angket sebanyak 10 butir pertanyaan yang dibagikan kepada 10 responden. Sebanyak $96 \%$ indikator mendapat tanggapan sangat setuju dan $4 \%$ indikator mendapat tanggapan setuju dari audiens uji coba satu lawan satu. Sehingga dihasilkan nilai 39.5 dari 40. Kemudian dilaksanakan rekapitulasi untuk keseluruhan perspektif. Berlandaskan pengorganisasian data uji coba satu lawan satu yang telah dikumpulkan, dihasilkan tingkat persentase keseluruhan aspek sebanyak 98,75\%. Berlandaskan tafsiran data, tergolong dalam kualifikasi A dengan persentase $85 \%$ - $100 \%$ maka media yang diciptakan tersebut tergolong dalam kualitas valid dan layak diaplikasikan untuk proses belajar mengajar. 


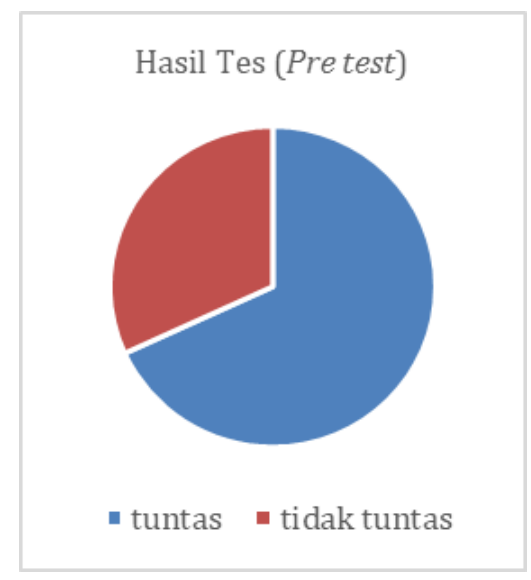

Grafik 1. Hasil Pre-test

Pada uji coba pre-test dihasilkan data sebanyak 15 anak didik rampung dalam menyelesaikan soal evaluasi yang telah diberikan, dan sebanyak 7 anak didik lainnya tidak rampung mengerjakan soal yang diberikan.

Pada uji coba post test dihasilkan data sebanyak 21 anak didik rampung dalam menyelesaikan soal evaluasi yang telah diberikan, dan sebenyak 1 anak didik lainnya tidak rampung mengerjakan soal yang diberikan karena berhalangan mengikuti tes belajar dalam penelitian.

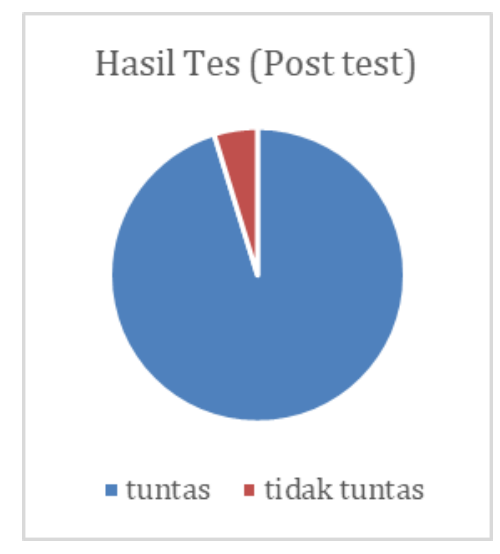

\section{Grafik 2. Hasil Post-test}

\section{PEMBAHASAN}

Media video pembelajaran merupakan media yang menyajikan audio dan visual yang mengandung pesan-pesan pembelajaran baik yang berisi konsep, prosedur, prinsip, teori aplikasi pengetahuan untuk membantu pemahaman terhadap suatu materi pembelajaran (Cheppy Riyana, 2007). Kombinasi antara materi visual dan audio pendidik dapat menciptakan proses pembelajaran yang lebih berkualitas karena komunukasi berlangsung lebih efektif (Prastowo, 2014). Penyelidikan literatur kurang lebih 50 tahun dan menyatakan bahwa penyajian yang menggunakan audio dan visual memberikan pengetahuan lebih banyak dari pada jika hanya menggunakan salah satu dari dua indera tersebut (Prastowo, 2014).

Nashrullah (2018) menjelaskan bahwa media video pembelajaran berhasil mempengaruhi minat belajar anak didik. Hal itu selaras dengan penelitian Faisal (2019) yang menjelaskan bahwa media video pembelajaran dapat menumbuhkan rasa antusias dan senang anak didik dalam aktivitas belajar mengajar. Kurniawan (2018) menejalaskan bahwa media video yang layak dapat mengoptimalkan hasil belajar anak didik. Hal itu selaras dengan temuan penelitian Alamsyah 
(2018) yang menjelaskan bahwa media video dapat membantu aktivitas belajar mengajar menjadi menarik bagi anak didik (Luhulima, 2018). Pernyataan yang selaras disampaikan oleh Hapsari (2018) yang menjelaskan bahwa media video yang memenuhi prinsip multimedia dapat meningkatkan minat belajar dan hasil belajar anak didik. Pernyataan yang selaras di sampaikan oleh Woottipong (2014) yang menjelaskan bahwa media video menjadi berpengaruh pada hasil belajar dan keterampilan anak didik yang diteliti. Peneltian yang dilaksanakan Nugroho (2015) menjelaskan bahwa media video menjadi berpengaruh terhadap hasil belajar dan keterampilan anak didik yang diteliti. Penelitian yang dilaksanakan Aldian (2019) menyatakan bahwa media video pembelajaran dapat mendukung pendidik dalam aktivitas pembelajaran.

Hasil pengembangan video pembelajaran pada penelitian ini telah divalidasi oleh ahli materi, ahli media dan audiens (anak didik). Media video pembelajaran tersebut dinyatakan valid dan layak untuk diaplikasikan sebagai media pembelajaran pada tema 8 subtema 1 pembelajaran 1 materi manusia dan lingkungan kelas V MI Ar-Raudhah Lawang. Hal tersebut dibuktikan dengan dengan hasil perhitungan statistik yaitu dari ahli materi dihasilkan hasil skor persentase sebesar 90\%. Berlandaskan tafsiran data, tergolong dalam kualifikasi A dengan persentase $85 \%-100 \%$ maka media yang diciptakan tersebut tergolong dalam kualitas valid dan layak diaplikasikan untuk proses belajar mengajar.

Hasil perhitungan statistik dari ahli media dihasilkan hasil skor persentase sebesar 87,5\%. Berlandaskan tafsiran data, tergolong dalam kualifikasi A dengan persentase 85\% - 100\% maka media yang diciptakan tersebut tergolong dalam kualitas valid dan layak diaplikasikan untuk proses belajar mengajar.

Pada uji coba satu lawan satu dilakukan penelitian berbentuk angket sebanyak 10 butir pertanyaan yang dibagikan kepada 10 responden dan dihasilkan hasil skor persentase sebesar $95 \%$. Berlandaskan tafsiran data, tergolong dalam kualifikasi A dengan persentase 85\% - 100\% maka media yang diciptakan tersebut tergolong dalam kualitas valid dan layak diaplikasikan untuk proses belajar mengajar.

Pada uji coba pada kelompok kecil dilakukan penelitian berbentuk angket sebanyak 10 butir pertanyaan yang dibagikan kepada 10 responden dan dihasilkan hasil skor persentase sebesar 98,75\%. Berlandaskan tafsiran data, tergolong dalam kualifikasi A dengan persentase $85 \%-100 \%$ maka media yang diciptakan tersebut tergolong dalam kualitas valid dan layak diaplikasikan untuk proses belajar mengajar.

Pada uji coba pre-test dihasilkan data sebanyak 15 anak didik rampung dalam menyelesaikan soal tes hasil yang telah diberikan, dan sebanyak 7 anak didik lainnya tidak rampung mengerjakan soal yang diberikan. Sehingga persentase anak didik yang rampung pada uji coba pre-test sebesar $68 \%$.

Pada uji coba pre-test dihasilkan data sebanyak 21 anak didik rampung dalam menyelesaikan soal tes hasil yang telah diberikan, dan sebanyak 1 anak didik lainnya tidak rampung mengerjakan soal yang diberikan karena berhalangan tidak bisa mengikuti tes hasil belajar. Sehingga persentase anak didik yang rampung pada uji coba pre-test sebesar $95 \%$.

Berdasarkan angket yang telah diberikan kepada ahli media, dihasilkan tanggapan bahwasannya sumber dari klip video perlu disertakan, walaupun ada beberapa bagian yang perlu dikonfirmasikan jika itu bukan hasil take pribadi. Setelah diuji cobakan kepada ahli media, dilakukan revisi pada media video pembelajaran berupa penambahan teks keterangan sumber klip video pada video yang diaplikasikan. 
Berdasarkan angket yang telah diberikan kepada ahli materi, dihasilkan tanggapan bahwasannya perlu ditambahkannya materi tambahan pada bagian akhir video. Materi tambahan tersebut yaitu poin terakhir dalam RPP berbentuk materi tentang "Pentingnya disiplin". Agar memudahkan anak didik dalam mempelajari materi tersebut dapat disajikan dengan klip video berbentuk dialog antar manusia tentang materi pentingnya disiplin. Tanggapan selanjutnya dari ahli materi adalah penambahan PR (Pekerjaan Rumah) atau tugas agar anak didik dapat lebih mendalami materi pada pembelajaran tema 8 subtema 1 pembelajaran 1 tentang manusia dan lingkungan. Setelah diuji cobakan kepada ahli materi, dilakukan revisi pambahkan klip video dengan materi tentang pentingnya disiplin berbentuk video kartun agar menambah kemenarikan media video pembelajaran terhadap anak didik. Selanjutnya juga penambahan PR (Pekerjaan Rumah) atau tugas pada bagian akhir video pembelajaran untuk dikerjakan oleh anak didik di rumah.

Berdasarkan angket yang telah diberikan kepada anak didik pada uji coba satu lawan satu, dihasilkan tanggapan bahwasannya media video pembelajaran mampu menambah minat belajar anak didik dan mampu membuat suasana pembelajaran lebih nyaman dan menyenangkan. Berdasarkan angket yang telah diberikan kepada anak didik pada uji coba kelompok kecil, dihasilkan tanggapan bahwasannya media video pembelajaran mampu membuat suasana pembelajaran menjadi tidak jenuh dan menambah minat belajar peserta duduk. Setelah diuji cobakan pada anak didik, pengembang mendapat masukan untuk lebih baik lagi dalam merancang dan membuat media video pembelajaran agar persentase tercapainya tujuan pembelajaran semakin meningkat serta menambah minat belajar anak didik.

Setelah proses validasi kepada ahli materi dan ahli media serta ujicoba kepada anak didik melalui uji coba satu lawan satu dan uji coba kelompok kecil, telah dilakukan perbaikan media video pembelajaran bedasarkan komentar dan saranyang telah dihasilkan. Dengan revisi tersebut media video pembelajaran pada tema 8 subtema 1 pembelajaran 1 materi manusia dan lingkungan kelas V MI Ar-Raudhah Lawang layak diaplikasikan dalam aktivitas pembelajaran. Belajar yaitu proses mental yang terjadi akibat dari interaksi antara individu yang belajar terhadap lingkungan dan sumber belajar. Proses pembelajaran berbantukan media akan terjadi secara efektif apabila digabungkan dengan penggunaan metode dan model pembelajaran yang mendukung (Surahman et al., 2018). Selain itu pendidik harus menentukan jenis evaluasi yang dapat mengukur secara objektif capaian belajar anak didik. Dalam konteks pembelajaran orang dewasa, maka pelibatan pebelajar untuk memberikan penilaian menjadi faktor yang perlu diperhatikan. Penggunaan media video pembelajaran akan lebih optimal apabila media video pembalajaran didesain dalam bentuk pembelajaran bergerak (mobile learning) (Georgiev, Georgieva, \& Smrikarov, 2004), (Korucu \& Alkan, 2011), (Praherdhiono et al., 2019). Hal tersebut dikarenakan proses belajar mengajar mampu dilakukan dimana saja dan kapan saja. Aktivitas pembelajaran tersebut mampu membantu proses pencapaian tujuan pemebelajaran secara efektif dan efisien.

\section{SIMPULAN}

Media pembelajaran video tema 8 subtema 1 pembelajaran 1 materi manusia dan lingkungan untuk kelas 5 mampu membantu dalam aktivitas pembelajaran. Penilaian yang cukup positif dari ahli materi dan juga ahli media adalah video pembelajaran tersebut dikatakan cukup valid dan layak untuk diaplikasikan dalam proses aktivitas pembelajaran. Dalam uji coba satu lawan satu, kelompok kecil, dan pada kelompok besar dihasilkan hasil valid dan layak diaplikasikan oleh pendidik. Namun adanya kritik dan saran dari ahli materi, ahli media, maupun anak didik seperti penambahan materi ekstra, bahkan pencantuman sumber klip video. Dilihat dari hasil pre-test dan juga post-test dihasilkan hasil yang signifikan dalam peningkatannya sehingga mampu dikatakan 
penggunaan media pembelajaran video tema 8 subtema 1 materi manusia dan lingkungan untuk kelas 5 dapat diaplikasikan dalam aktivitas belajar mengajar.

\section{DAFTAR RUJUKAN}

Agustiningsih, A. (2015). Video Sebagai Alternatif Media Pembelajaran Dalam Rangka Mendukung Keberhasilan Penerapan Kurikulum 2013 di Sekolah Dasar. PEDAGOGIA: Jurnal Pendidikan, 4(1), 50-58.

Alamsyah, R., Toenlioe, A. J., \& Husna, A. (2019). Pengembangan video pembelajaran kepenyiaran materi produksi program televisi untuk mahasiswa Teknologi Pendidikan Universitas Negeri Malang. Jurnal Kajian Teknologi Pendidikan, 1(3), 229-236.

Alfindasari, D., \& Surahman, E. (2014). Sumber Daya Manusia dan Pendidikan di Era Global: Sebuah Tinjauan Terhadap Penelitian Teknologi Pendidikan di LPTK. Proceeding Seminar Nasional Teknologi Pembelajaran. Yogyakarta: UNY.

Arikunto, S, \& Jabar, C.S.A. (2014). Evaluasi Program Pendidikan. Jakarta: Bumi Aksara.

Arsyad, Azhar (2006). Media Pendidikan. Jakarta: PT. Raja Grafindo Persada.

Arif, M. F., Praherdhiono, H., \& Adi, E. P. (2019). Pengembangan Video Pembelajaran IPA Materi Gaya untuk Siswa Sekolah Dasar. Jurnal Kajian Teknologi Pendidikan, 2(4), 329335. Georgiev, T., Georgieva, E., \& Smrikarov, A. (2004). M-Learning-a New Stage of ELearning. 2008 International Conference on Machine Learning and Cybernetics.

Hapsari, N. D., Toenlioe, A. J., \& Soepriyanto, Y. (2019). Pengembangan Augmented Reality Video Sebagai Suplemen Pada Modul Bahasa Isyarat. Jurnal Kajian Teknologi Pendidikan, 1(3), 185-194.

Hernawan, A. H., Zaman, B., \& Riyana, C. (2007). Media pembelajaran sekolah dasar. UPI Press. Bandung.

Korucu, A. T., \& Alkan, A. (2011). Differences between m-learning (mobile learning) and elearning, basic terminology and usage of m-learning in education. Procedia-Social and Behavioral Sciences, 15, 1925-1930.

Kurniawan, D. C., Kuswandi, D., \& Husna, A. (2018). Pengembangan media video pembelajaran pada mata pelajaran IPA tentang sifat dan perubahan wujud benda kelas IV SDN Merjosari 5 Malang. JINOTEP (Jurnal Inovasi dan Teknologi Pembelajaran): Kajian dan Riset Dalam Teknologi Pembelajaran, 4(2), 119-125.

Luhulima, D. A., Degeng, N. S., \& Ulfa, S. (2018). Pengembangan Video Pembelajaran Karakter Mengampuni Berbasis Animasi Untuk Anak Sekolah Minggu. JINOTEP (Jurnal Inovasi dan Teknologi Pembelajaran): Kajian dan Riset Dalam Teknologi Pembelajaran, 3(2), 110-120.

Mayer, R. E., \& Moreno, R. (1998). A cognitive theory of multimedia learning: Implications for design principles. Journal of educational psychology, 91(2), 358-368.

Mayer, R., \& Mayer, R. E. (Eds.). (2005). The Cambridge handbook of multimedia learning. Cambridge university press.

Melinda, V. A., Degeng, N. S., \& Kuswandi, D. (2018). Pengembangan Media Video Pembelajaran Ips Berbasis Virtual Field Trip (Vft) Pada Kelas V Sdnu Kratonkencong. JINOTEP (Jurnal Inovasi dan Teknologi Pembelajaran): Kajian dan Riset Dalam Teknologi Pembelajaran, 3(2), 158-164.

Mulyono, A. B., Abidin, Z., \& Husna, A. (2019). Pengembangan Media Video Pengoperasian Kamera DSLR Sebagai Suplemen Mata Pelajaran Di Jurusan Multimedia. Jurnal Kajian Teknologi Pendidikan, 2(4), 290-296.

Nashrullah, N., Sulton, S., \& Soepriyanto, Y. (2019). Pengembangan Video Pembelajaran Adaptasi Dan Cara Berkembang Biak Makhluk Hidup Untuk Siswa Kelas Vi Sekolah Dasar. Jurnal Kajian Teknologi Pendidikan, 1(4), 327-332. 
Nugroho, T. A. T. (2015). Pengaruh Penggunaan Media Video Pembelajaran terhadap Keterampilan Proses IPA dan Hasil Belajar IPA pada Siswa Kelas V SD Negeri Rejowinangun 1 Yogyakarta Tahun Ajaran 2014/2015. Skripsi, Universitas Negeri Yogyakarta, PGSD, Yogyakarta.

Praherdhiono, H., \& Adi, E. P. (2008). Panduan Praktikum Multimedia. Malang: Fakultas Ilmu Pendidikan Universitas Negeri Malang

Praherdhiono, H., Setyosari, P., Degeng, I. N. S., Slamet, T. I., Surahman, E., Adi, E. P., ... Abidin, Z. (2019). Teori Dan Implementasi Teknologi Pendidikan: Era Belajar Abad 21 dan Revolusi Industri 4.0. Seribu Bintang

Pramudito, A. (2013). Pengembangan media pembelajaran video tutorial pada mata pelajaran kompetensi kejuruan standar kompetensi melakukan pekerjaan dengan mesin bubut di SMK Muhammadiyah 1 Playen. Jurnal Pendidikan Teknik Mesin, 1(1), 1-12.

Prastowo, Andi. (2014). Pengembangan Bahan Ajar Tematik: Tinjauan Teoretis dan Praktik. Jakarta: Kencana. Simanjuntak, A.L.

Riyana, C. (2007). Pedoman pengembangan media video. Jakarta: P3ai Upi.

Sadiman. (2011). Media Pendidikan, Pengertian, Pengembangan, dan Pemanfaatannya. Jakarta: PT. Raja Grafindo Persada.

Susilana, R., \& Riyana, C. (2008). Media pembelajaran: hakikat, pengembangan, pemanfaatan, dan penilaian. CV. Wacana Prima.

Woottipong, K. (2014). Effect of using video materials in the teaching of listening skills for university students. International Journal of Linguistics, 6(4), 200. 